\title{
The Promise of Feminist Philosophy
}

\author{
BONNIE MANN, ERIN MCKENNA, CAMISHA RUSSELL, AND \\ ROCÍO ZAMBRANA
}

Sara Ahmed begins Living a Feminist Life with a reflection on the word "feminism," and she claims to have written the book "as a way of holding onto the promise of that word" (Ahmed 2017, 1). Ahmed is explicit in noting that by "feminism" she means intersectional feminism, and for her, the promise of the word "feminism" is far-reaching.

It is a word that fills me with hope, with energy. It brings to mind loud acts of refusal and rebellion as well as the quiet ways we might have of not holding on to things that diminish us. It brings to mind women who have stood up, spoken back, risked lives, homes, relationships, in the struggle for more bearable worlds. It brings to mind books written, tattered and worn, books that gave words to something, a feeling, a sense of an injustice, books that, in giving us words, gave us the strength to go on. Feminism: how we pick each other up. So much history in a word, so much it too has picked up. (1)

Her description speaks to the ways so many of us have been picked up by feminism, the exhilaration we have felt reading feminist works, engaging in feminist conversations and feminist activism. In this passage she connects the promise of feminism with the specific histories of women who have refused the things that diminish us. So there is a past, or there are many pasts, that are born of an aspiration to more bearable futures. We inherit the aspirational promise of feminism and through it we sometimes lift one another up.

When the four of us made the decision to apply to become the new co-editors of Hypatia: A Journal of Feminist Philosophy, it was the power of that promise that compelled us. As daunted as we were by the weight of the controversy that had engulfed the journal and its various constituencies, as much as we disagreed with one another in our specific responses to that controversy - across our own philosophical, demographic, and political differences-we all shared the sense that Hypatia was worth fighting for. We shared the hope that Hypatia could realize its better nature, renew its long-standing aspiration to be a source of the writing that gives words to experience, articulates the meanings of injustice, and gives us strength to go on. We were gripped by a sense of the importance of such work in a context in which feminist 
gains remain fragile and antifeminist commitments are a cornerstone of burgeoning authoritarian political trends globally.

If Hypatia is to realize its better nature, however, we must be willing to acknowledge that the word "feminism" has a complex and self-contradictory history. "So much history in a word, so much it too has picked up" (Ahmed 2017, 1). The troubled "we" of feminism, "that hopeful signifier of a feminist collectivity" (2), collects and intensifies tensions around the word "feminism." Racism, colonial control, reinforcement of modes of material inequality, political exclusion, and social sanction sometimes travel under the banner of "feminism," are sometimes entangled with feminist thinking and practice, and sometimes appropriate feminist demands for their own ends. While the word "feminism" is associated with hope and renewal in some contexts, at some times, for many of us, it also carries historical associations of betrayal, dismissal, privileged indifference, and willful ignorance in relation to crossed relations of power. "Where there is hope, there is difficulty," Ahmed writes, "feminist histories are histories of the difficulty of that we, a history of those who have had to fight to be part of a feminist collective, or even had to fight against a feminist collective in order to take up a feminist cause" (2).

Hypatia is as much a part of this vexed history as any feminist endeavor. The journal's hard-won standing in the world of academic publishing (having fought for and achieved a status that previous generations of feminist thinkers could not have imagined for a feminist publication) has necessarily come at the cost of its entanglement in the professional practices, managerial and administrative norms, and discursive conventions that are part of the machinery that tends to maintain historical patterns of exclusion and suppression. Hypatia has become an avenue for many junior scholars to achieve the professional legitimation required to succeed in academic life, it has published groundbreaking work that has literally changed the status of feminist thought in professional philosophy, and at the same time it also finds itself in the position of being experienced by many scholars who find their marginalization in the discipline to be tenacious and unremitting as an institutionalized site of the reproduction of that exclusion. Living up to Hypatia's promise requires navigating these complex and contradictory realities, it means listening to the grievances of those the journal has failed to welcome and failed to hear, it requires a renewed invitation to the journal's intended community to criticize, reflect, and hold Hypatia to account.

But the "total concrete situation" (Beauvoir 2010) in which we take on the editorship of Hypatia is more complex still. We begin this work at a historical moment in which any conflict among feminists will be seized on by antifeminists as a way of furthering their cause. Most immediately, antifeminist elements in the discipline of philosophy and academia more broadly are anxious to publicize the shortcomings of institutionalized feminist endeavors as evidence for the illegitimacy of feminism tout court. We have to recognize that feminist achievements are fragile; they have to be protected or they will be undone. It is important, however, not to react to this reality impulsively and defensively through efforts to shut down dissent. Creating practices of and promoting values consistent with engaging dissent, and changing as a result of dissent, have to be at the core of our work in order to strengthen and protect 
feminist gains. Camisha has suggested that there are three important elements to this commitment: "(1) the need for close attention to social context in order to avoid uncritically reifying assumptions that support current social and political inequalities, (2) the challenging of any stance's claim to political neutrality and the acknowledgement of one's own partiality and founding assumptions, and (3) a willingness to engage in and to remain engaged in continual criticism and self-reflection" (Russell 2018, 26).

This is even more important given the broader political context. Feminist demands are achieving a public urgency, international scope and broad visibility through the \#MeToo, \#Times $\mathrm{Up}$, and \#NiUnaMenos social-media campaigns, massive women's marches, including protests "from Buenos Aires and Sao Paulo to Mexico City and Santiago" against femicide (Hatch 2016), and (at least in the US) the unprecedented numbers of women running for public office. Women's strikes and protests around the world led Cinzia Arruza to announce, at the end of 2018, the arrival of a "third feminist wave" in the form of a "new class movement." "While the second feminist wave, in the Sixties and Seventies, had a core of advanced capitalist Western countries as its centers of propulsion," she writes, "the current feminist wave was born from the "periphery'-from Argentina and Poland - and it rapidly spread to a global level, assuming a mass dimension in a series of countries most affected by the crisis and by austerity and debt containment policies (Italy, Spain, Brazil, Chile...)" (Arruza 2018). Antiracist activists and those supporting immigrants and refugees are achieving an unprecedented public visibility internationally. Simultaneously, rightwing nationalist movements in many parts of the world are making antifeminist commitments an explicit and central part of their public platforms. As the Washington Post reported in January of 2018, the authoritarian, nationalist government of Poland has moved to strip women of their reproductive rights, raided feminist organizations and taken away their funding; the president of the Philippines built his brash public image in part by telling rape jokes; the Turkish president has issued repeated appeals to women's maternal destiny as a core cultural value; Russia's Putin appointed antifeminist women to public positions in order to put right-wing, repressive politics into practice; and the US president, dubbed "misogynist in chief" by women's rights activists, was elected in part on the popular appeal of his frequent sexist attacks on women and his public promise to overturn women's reproductive rights (Tharoor 2018). The explicit sexism of these movements is enmeshed with their even more explicit racism and brutal anti-immigrant and antirefugee policies.

Where authoritarian political movements are on the rise, we also find a disdain for thinking, for reasoned deliberation, and along with these, disdain for the moral worth of the vulnerable. Hannah Arendt's description of an era when facts and events are "infinitely fragile" (Arendt 2006, 227) in the face of "organized lying" that involves lies "so big they require a complete rearrangement of the whole factual texture - the making of another reality" (248) could not be better suited to our own times. For Arendt, the counterweight to organized lying is an "enlarged mentality" that is achieved only through putting oneself into the shoes of the other, of many others, and thinking from the perspective that engaging many perspectives enables 
(217). Times like these intensify the urgency of picking each other up through committed feminist thinking and practice.

Hypatia's specific history in this regard is complex. The journal's editors have often addressed questions of disciplinary pluralism, demographic exclusion and marginalization, and the journal's own role in setting the agenda for feminist agitation or compliance within the academy. From 2010-2012, for example, the journal's annual reports reflect a substantial, ongoing discussion about making Hypatia "robustly and proactively inclusive," which included the formation of a "diversity advisory group" (convened by Linda Alcoff, including Kristie Dotson, Kathryn Gines, Mariana Ortega, Uma Narayan, and Ofelia Schutte) to make recommendations to the editors and co-editors. Their efforts included making financial commitments to support scholars' work that engages "the diversity within feminism, the diverse experiences and situations of women, and the diverse forms that gender takes across the globe" through essay prizes, travel support, and other forms of funding.

One vehicle for engaging dissent at certain points in Hypatia's history was the inclusion of a "Comment/Reply" section. In this section, debates over the meaning of pluralism occurred, and the question of whether or not Hypatia was locked into a nonconfrontational approach in relation to the larger discipline was debated (Lindgren 1990, 5.1; Urban-Walker 1990, 5.1). The costs of academic legitimacy were thematized, questions about the potential limits of academic interventions, the politics and strictures of seeing Hypatia primarily as a way for junior scholars to obtain tenure, and the potentially compromising task of securing recognition in the context of the academy were described and analyzed (Holmes 1990, 5.3; Frances 1990, 5.3; Triglio 1991, 6.2). Special issues have served many purposes, but one purpose has been to provide a forum for engaging difference and dissent. Hypatia has taken on the issue of philosophical pluralism or its absence, for example, in its own pages. Charlene Haddock Seigfried challenged the pragmatist tradition to stop neglecting feminism and feminists to stop neglecting pragmatism in a Hypatia article (Seigfried 1991, 6.2) and followed up with a special issue on feminist pragmatism (Seigfried 1993, 8.2), with another special issue entitled Women in the American Philosophical Tradition 18001930 appearing years later (Rogers and Dykeman 2004, 15.2). Analytic feminist philosophy as a distinctive tradition was the topic of two special issues (Cudd and Klenk 1995, 10.3; Superperson and Brennan 2005, 20.4). The special issue structure has sometimes allowed Hypatia to create space for scholars who are subjected to the most persistent forms of marginalization in the discipline, and for intersectional feminist work, even as Hypatia as a whole has been justly criticized for the underrepresentation of such work. In 1998, a double-volume special issue thematized multicultural and postcolonial feminist challenges to philosophy and the need for feminists to engage internationally (Narayan and Harding 1998, 13.2, 13.3) and was followed by two additional special issues speaking to these themes (Scholtz 2013, 28.2; Herr and Park 2017, 32.3). Special issues were published on women of color feminism (Dotson 2014, 29.1), feminism and disability (Kittay, Silvers, and Wendell 2001, 16.4; 2002, 17.3; Hall 2015, 30.1), indigenous women (Talamantez, Guerro, and Waters 2003, 18.2), heterosexism (Callahan, Mann, and Ruddick 2007, 22.1), and transgender 
studies (Bettcher and Garry 2009, 24.3). More recently, the development of Hypatia clusters (a set of three or more articles on a single theme in an open issue) offers another avenue that might be employed to highlight work that is marginalized in the larger discipline (see, for example, the Latina feminist philosophy cluster in issue 31.2, 2016).

Although this history reflects admirable efforts to create space for scholarship produced at the margins of feminist philosophy and the discipline more broadly, it is not necessarily the case that creating space for these voices amounts to a willingness to be changed by them, nor that such efforts seamlessly achieve the hoped-for results. Rocío's understanding of the "normative ambivalence" of action provides a crucial caution here.

To act is to attempt to express an intention publically [sic]. But this means that the determinacy of an action is not fully up to the agent. It is a matter of its externality - its "publicity," for instance.... The determinacy of deeds, moral worth, even intentions can only be established in light of the temporal extension and intersubjective character of action, hence in light of misfires, competing interpretations, unforeseen consequences, incongruent normative expectations, and so on, that exceed the intentions of the agent.... Along these lines, spaces of resistance, as well as philosophy as a critical practice, are always subject to normative instability, cooption, to coextensive positive and negative meanings and effects... .This means that any material or discursive gain against systems of oppression is fragile, "precarious," in need of being maintained, even radically transformed in light of new material and historical conditions. (Zambrana 2019)

We understand Hypatia to be one of those precarious spaces of resistance, where intentions and outcomes do not perfectly mirror each other. We see Hypatia as aspiring to a critical practice that must be vigilantly maintained even as it remains open to radical transformation, as new historical and material conditions present themselves.

The new editorial team of Hypatia is the most diverse in its history, philosophically, demographically, and in terms of our professional age/status in the discipline (with one assistant, one associate, and two full professors). Each of us has felt her own versions of gratitude for and critical distance from Hypatia over the years. Coming together as a team is an ongoing process of recognizing our differences related to our historically burdened relationships to feminism and the discipline of philosophy as a whole, acknowledging our disagreements, and building trust with one another across those divides. The larger team includes our managing editor, Sarah LaChanceAdams, Joan Woolfrey, the co-editor of Hypatia Reviews Online who graciously agreed to continue until we are able to find a replacement, our two graduate student employees, Eli Portella (editorial assistant) and Kaja Rathe (Hypatia Reviews Online managing editor). The one thing we all have in common is our connection with the University of Oregon, since all of us have been part of UO's graduate program in 
philosophy either as faculty or as students. All of us have undertaken our work for Hypatia while the nonprofit board and the interim task force are still working to put new governance structures in place, and while Hypatia is in the midst of reflecting on the question of feminist publication ethics in an expansive way, without yet having a full set of principles or guidelines in place.

It is clear that there must be an ongoing conversation about publication ethics that extends from questions of policy to questions of unwitting complicity in historical patterns of marginalization and exclusion. Though the editorial team does not actually determine or control Hypatia's policies - those are to be reworked by a broader constituency - we will be responsible for implementing them. This implementation must go beyond a set of policies to include habituating sensitivity to how citational practices, processes of review, and recognized discursive conventions are implicated in structures of power. This broader view will prevent the reduction of the conversation to a liberal affirmation of the right to "free speech," since it recognizes the ways in which access to the means of speech is as much a product of reified relations of power as it is an achievement of our liberatory strivings. Taking historically sedimented vulnerabilities into account will require more care than our traditional, only apparently neutral practices of gatekeeping require. Citing Alain Locke's assertion that "in this value domain mutual respect and reciprocity, based on nonaggression and nondisparagement can alone be regarded as justifiable" (Locke 1991, 101), Erin writes, "This means remaining open ourselves, but not to the point of allowing aggressive attacks, unwarranted disparagement, and attempts at erasure" (McKenna 2017, 11).

At the same time, feminist work requires the recognition that there are no pure places to which we can retreat. As Bonnie puts it:

There is no "free space" immunized from patterns of injustice. Our cultural moment is characterized by the blatant affirmation of racism, sexism and other modes of injustice on the one hand, and on the other hand by a reactive fantasy of innocence or purity that sets itself up as the counterpoint to aggressive misogyny and racism. The two sides mirror one another at least in this: the one side demands the purification of a "homespace" from different others, while the other demands the creation of a "home-space" purified of not only those who embrace and affirm such injustices, but also all those who might act unjustly. The problem with this fantasy of purification is that it is doomed to fail - all of us are liable to enact injustice because the structures of injustice are crossed, complex, and also structure the material relations in which we are bound. The fantasy of purity allows no room for mistakes, thus no room for growth, and no room for change. The pure room becomes the empty room, eventually. (personal correspondence 2019)

The co-editors of Hypatia are very clear that we are fallible in the pragmatist sense of that term, that Hypatia as a project must keep its own fallibility in sight rather than suppress or deny it. The key to pragmatic fallibility is contestation and change. We 
call on the entire Hypatia community to hold us to account, to name failures when they occur, and strive with us for positive transformation.

\section{REFERENCES}

Ahmed, Sara. 2017. Living a feminist life. Durham, N.C.: Duke University Press.

Arendt, Hannah. 2006. Between past and future: Eight exercises in political thought. 2nd ed. New York: Viking.

Arruza, Cinzia. 2018. From women's strikes to a new class movement: The third feminist wave. https://www.viewpointmag.com/2018/12/03/from-womens-strikes-to-a-new-cla ssmovement-the-third-feminist-wave/.

Beauvoir, Simone de. 2010. The second sex. New York: Vintage Books.

Hatch, Jenavieve. 2016. 27 Powerful images of women protesting against femicide in Latin America. Huffington Post, October 20. https://www.huffingtonpost.com/entry/28-powe rful-images-of-women-protesting-against-femicide-in-latin-america_us_5807cd67e4b Ob994d4c3856e.

Locke, Alain Leroy. 1991. Pluralism and ideological peace in the philosophy of Alain Locke: Harlem Renaissance and beyond, ed. Leonard Harris. Philadelphia: Temple University Press.

McKenna, Erin. 2017. The need for reciprocity and respect in philosophy. The Pluralist 12 (1): $1-14$.

Russell, Camisha A. 2018. The assisted reproduction of race. Bloomington: Indiana University Press.

Tharoor, Ishaan. 2018. How anti-feminism is shaping world politics. Washington Post, January 30. https://www.washingtonpost.com/news/worldviews/wp/2018/01/30/how-antifeminism-is-shaping-world-politics/?utm_term=.5a64ceee7a68.

Zambrana, Rocío. 2019. Hegelian interviews: Rocío Zambrana. HegelPD. http://www.hege lpd.it/hegel/print/?articolo=14510. 